\title{
Online Absention System As Implementation Of Asn Management In The New Normal Era In Jambi Province
}

\author{
Asti Harkeni ${ }^{1}$ and Novia Susianti ${ }^{2}$ \\ ${ }^{12}$ Jambi Province Regional Research and Development Agency \\ Correspondent: asti.harkeni@gmail.com
}

Submitted : October 21, $2020 \quad$ Revised : October 25, 2020 Published : October 30, 2020

\begin{abstract}
Since the issuance of Presidential Decree (Keppres) No. 11 of 2020 concerning the Establishment of Public Health Emergency COVID-19 and Circular Letter of the National Personnel Agency (BKN) Number 11/SE/IV/2020 concerning the Guidelines for Disciplinary Punishment for State Civil Apparatus (ASN) Conducting Travel Activities Outside the Region and/or Going Home during the Emergency Public Health Period, Jambi Provincial Government implements an online attendance policy through the SiAbOn application installed on a smartphone. The goal is to monitor the location of the presence of the ASN during Eid al-Fitr holidays from 23 to 25 May 2020, as well as concrete efforts to stop the spread of COVID-19. The research problem formulation is to see how the effectiveness and efficiency as well as the impact of the SiAbOn application on the implementation of ASN management in the new normal era. Data sources were obtained from ASN, Department of Communication and Information (Dinas Kominfo), and Jambi Province Regional Personnel Agency (BKD Prov. Jambi). The sample location is Jambi Province. The research method used was quantitative. The results showed that out of 11,214 ASNs, 92.37\% (10,351 ASNs) used SiAbOn, while 7.70\% (863 ASNs) did not. These results are very satisfying considering the preparation time until the implementation was very short, only 14 days with an ASN area of more than $600 \mathrm{~km} 2$, geographical challenges, and limited internet infrastructure. The SiAbOn implementation policy during the Eid holiday then was adopted as a permanent policy in the new normal era replacing the obligation to record attendance using a hand-key machine which could be the source of COVID-19 spread.
\end{abstract}

Keywords: New Normal, Online Attendance, Jambi Province

\section{INTRODUCTION}

World Health Organization (WHO) declared Covid-19 as a Global Pandemic on March $11^{\text {th }} 2020$, taking into account that non-natural disasters caused by the spread of Corona Virus Disease 2019 (COVID-19) had an impact on increasing the number of victims and property losses (Keputusan Presiden Republik Indonesia, 2020). The President of the Republic of Indonesia issued Presidential Decree Number 11 of 2020 concerning the Determination of the Corona Virus Disease 2019 Public Health Emergency by considering the extent of the area affected by the disaster, as well as causing implications for broad socio- economic aspects for Indonesia (Sekretariat Kabinet Republik Indonesia, 2020). The President of the Republic of Indonesia then also issued Presidential Decree No. 12 of 2020 concerning the Determination of Non-natural Disaster in the Spread of Corona Virus Disease 2019 (COVID-19) as a National Disaster (Keputusan Presiden Republik Indonesia, 2020). 
Since the issuance of Presidential Decree No. 11 of 2020 concerning the Establishment of Public Health Emergency COVID-19 by the President of the Republic of Indonesia, the Republic of Indonesia State Personnel Agency issued Circular Letter Number 11/SE/IV/2020 concerning the Guidance to Discipline Punishment for State Civil Apparatuses Performing Traveling Activities Going Outside the Region and/or Mudik Activities during the Public Health Emergency Period (BKN, 2020). Then the Governor of Jambi issued Circular Number 921/SE/GUB- ORG$3.1 / 1 / 2020$ concerning Adjustment of the ASN work system in preventing the Spread of COVID19 within the Jambi Provincial Government (Pemerintah Provinsi Jambi, 2020). The Jambi Governor Circular was followed up by the Head of the Jambi Province Regional Staffing Agency (BKD) by issuing S-1195/BKD-4.2/V/2020 concerning Monitoring the Existence of ASN in the Framework of National Holidays and Joint Leave (Jambi Independent, 2020).

Pandemic Covid-19 causes ASNs to Work From Home and required to report their position/location through an Online Attendance application System called SiAbOn which can be downloaded using android smartphones through the link: https://bit.ly/SiAbOn. This reporting ASNs location through SiAbOn was conducted 2 (two) times a day by all ASNs in the Jambi Provincial Government environment during national holidays and joint leave of Eid alFitr at 07.00 to $09.00 \mathrm{WIB}$ (morning) and at 15.00 to $17.00 \mathrm{WIB}$ (afternoon) by activating Global Positioning System (GPS) / location mode on their android smartphones and sent selfphotos through the SiAbOn application. This activity must be done by all of the Jambi Provincial Government ASNs during national holidays and joint leave of Eid al-Fitr which took place from 23 to 25 May 2020. The applications of these new habits or new normal practices have an impact on the operational procedures for government services in Jambi Province. The Jambi Provincial Government adopted a work from home (WFH) system to protect the ASNs and also break the chain of COVID-19 infections; SiAbOn application is also a way to monitor and to discipline the employees.

This research objective is to find out how much is the benefits and impacts of the use of this Online Attendance System (SiAbOn) in the new normal era for ASNs in Jambi Province. The purpose of the SiAbOn application is to adjust the work systems and also an effort to prevent the continuous spread of COVID-19 within government agencies. It is also a way to ensure the implementation of restrictions on traveling outside the area and/or going home and/or on leave for ASNs during national holidays and joint leave. So it is required for each ASN in Jambi Provincial Government to download the SiAbOn application on their smartphone, which is useful for monitoring the presence of ASN during the Eid al-Fitr Day 1441 H / 2020 M.

Based on the problems in the background, the research problem formulation is how much is the effectiveness and efficiency of the SiAbon application for the ASNs in the Jambi Provincial Government during the new normal era and what is the impact of the SiAbon application on the implementation of ASNs management during the new normal era in the Jambi Provincial Government?

Management of State Civil Apparatus according to Law Number 5 of 2014 regarding State Civil Apparatus is the management of ASN to produce ASN employees who are professional, have basic values, professional ethics, are free from political intervention, corrupt practices, collusion, and nepotism (Undang Undang RI, 2014). Performance management is management about creating relationships and ensuring effective communication (Wibowo, 2007). Performance management focuses on what is needed by organizations, managers, and workers to succeed. Based on Government Regulation Number 11 the Year 2017 regarding Management of Civil Servants 
(PNS) management includes (Peraturan Pemerintah Republik Indonesia, 2017): (1) Preparation and establishment of needs; (2) Procurement; (3) Grade and Occupation; (4) Career Development; (5) Career Pattern; (6) Promotion; (7) Mutation; (8) Work Assessment:; (9) Payroll and Benefits; (10) Tribute; (11) Discipline; (12) Discharge; (13) Pension Insurance and Old Age Insurance; and (14) Protection.

Three things related to ASN management in the new normal era based on Government Regulation No. 11 of 2017 carried out by the Jambi Provincial Government through SiAbOn which is performance assessment, discipline, and protection.

Performance assessment is the process by which individual performance is measured and evaluated (Peraturan Pemerintah Republik Indonesia, 2017). Performance assessment is a formal method for measuring how well individual workers do their work concerning the given objectives. Performance assessment guarantees the objectivity of a civil servant (PNS) development based on achievement and career systems. Performance assessment is based on performance planning at the individual level and the unit or organization level, taking into account the targets, achievements, results, benefits achieved, and behavior of the civil servants. The assessment is carried out objectively, measured, accountable, participatory, and transparent.

Government Regulation of the Republic of Indonesia Number 53 of 2010 concerning the Discipline of Civil Servants states that Discipline of Civil Servants is the ability of Civil Servants to obey obligations and avoid prohibitions specified in statutory regulations and/or official regulations which if not obeyed or violated will be complied with disciplinary punishment (Peraturan Pemerintah Republik Indonesia, 2010). Disciplinary punishment for civil servants consists of three levels, namely disciplinary punishment mild, moderate, and severe.

Covid-19 pandemic is a test for the government in protecting citizens. ASN as part of a large group of people is entitled to protection from the government so as not to be infected with COVID-19. Law Number 5 of 2014 concerning the ASN paragraph 21 states that civil servants are entitled to get protection.

New lifestyle or new normal is a change in behavior to continue to carry out normal activities but with the addition of implementing health protocols to prevent COVID-19 transmission (Bramasta, 2020). Based on the information held by the Ministry of Health and the Task Force for the Acceleration of Handling COVID- 19, health protocols include: 1) keep hands clean, 2) do not touch the face in conditions of unclean hands, 3) wear masks, 4) keep distance to avoid occurrence virus exposure from person to person, 5) independent isolation for those who feel unwell. The new normal order is a transformation of life behavior in the community to continue to carry out normal activities but by implementing health protocols until the discovery of vaccines that can cure victims infected with COVID-19.

Online absention is an attendance recording using an application on a smartphone that is used by every employee or ASN whose data is collected and sent through the internet network that is processed through the SiAbOn application. This application runs on a cloud system that is connected in real-time with the user's smartphone. The cloud system stores attendance data automatically which then can be accessed anywhere and anytime while connected to the internet (Andini, 2019). The online absention system is built by utilizing computer technology and telecommunications technology to collect, send, and process data. Information technology is a combination of computer technology and telecommunications technology (Kadir \& Triwahyuni, 2013). The application that became known as SiAbOn is a software or information technology 
development program that was independently created by the employees of the Department of Communication and informatics of the Jambi Province, based on the protocol for implementing the work system according to new normal conditions. This application can assist ASN employees in the Jambi Provincial Government in reporting their location and is also useful to ensure the implementation of restrictions on traveling outside the area and/or going home and/or leave for the Jambi Provincial Government ASN during national holidays and leave together with Eid alFitr in 2020.

The SiAbOn application can be downloaded on an android smartphone via the link: https://bit.ly/SiAbOn, this application was not yet available on the Google Play Store at the time of the implementation of the National Holidays and Leave for Eid al-Fitr on 23rd May to 25th May 2020 because it still takes time for Google Play Store to verify the SiAbOn application, therefore employees can only install this application via the link above. This location reporting by ASNs through the SiAbOn was conducted 2 (two) times a day by all ASNs in the Jambi Provincial Government environment during national holidays and joint leave of Eid al-Fitr at 07.00 to $09.00 \mathrm{WIB}$ (morning) and at 15.00 to $17.00 \mathrm{WIB}$ (afternoon) by activating Global Positioning System (GPS) / location mode on their android smartphones and send self-photos through the SiAbOn application. This activity must be done by all of the Jambi Provincial Government ASNs during national holidays and joint leave of Eid al-Fitr which took place from 23rd May to 25th May 2020.

One of the studies that were conducted by Anantassa Fitri Andini and her team from FMIPA UNJ on the development of an android-based online attendance system was developed using the theory of software development in the spiral model (Andini, Irzal, \& Arafiyah, 2017). The spiral model has four stages of development that are applied, namely, the stages of communication, the stages of planning, the stages of modeling and design, and the stages of construction and development. College students can do their attendance online to produce time output when they are doing their attendance and lecturers can monitor and control the student's attendance process through an application on Android.

Similar research was also carried out by Fachrival Mustari (2018) to design and build an android application that makes it easy for teachers to make attendance at school. This type of research is qualitative and the results of this study are applications that utilize QRCode as the main component in helping the attendance of every teacher in SMP Negeri 1 Bulukumba with an android device (MUSTARI, 2018).

\section{METHODS}

This paper was made using quantitative analysis methods and data calculations using simple statistical analysis. Quantitative research methods are one type of research whose specifications are systematic, planned, and structured from the beginning to the design of the research. Another definition states that quantitative research is research that requires a lot of use of numbers, starting from data collection, interpretation of the data, and the appearance of the results. Likewise, at the conclusion stage of research, it would be better if accompanied by pictures, tables, graphs, or other views. The quantitative analysis method is research containing data and figures to be analyzed. Researchers use attendance tools in the form of applications/software called the Online Attendance System or SiAbOn. The steps undertaken in this study include: First, conducting a literature study. Second, collecting data / online attendance samples to relevant agencies, Third, conducting mathematical calculations for online absences from the absent recap 
of each OPD, and Fourth, analyzing data. The research instrument used was the online attendance system software (SIAbOn). Respondents in this study were Jambi Province ASN. Data sources are the Jambi Provincial Government ASN, the Department of Communication and Information, and the Jambi Provincial BKD. By sample, location is Jambi Province.

\section{RESULTS AND DISCUSSION}

ASN Management aims to produce ASN employees who are professional, have basic values, professional ethics, free from political intervention, free from corrupt practices, collusion, and nepotism. Referring to article 2 points (h), (k) and (n) of Government Regulation Number 11 of 2017 concerning the Management of Civil Servants, regarding the rights of Civil Servants (PNS) in the form of PNS protection and management including performance appraisal and discipline, the enactment of Work From Home (WFH) during the COVID-19 pandemic in Jambi Province, in particular, is appropriate. This is under the Circular from the Minister of Administrative Reform and Bureaucratic Reform No. 19 of 2020 concerning adjustments to the ASN work system to prevent the spread of COVID-19. This Circular is intended as a guideline for government agencies in carrying out official duties by working at home / their residence (work from home) for ASN in efforts to prevent and minimize the spread of COVID-19. Government agencies are required to carry out discipline enforcement of civil servants and carry out various efforts to improve discipline. This is what underlies the making of the Online Attendance System (SiAbOn) application for ASN in Jambi Province.

The number of ASNs in the Jambi Provincial Government is 11,214 people spread throughout the Regional Apparatus Organization (OPD). Data from the Central Statistics Agency in 2018 states that Jambi Province has an area of $50160.05 \mathrm{~km} 2$ consisting of 9 districts and 2 municipalities (BPS Provinsi Jambi, 2019). The furthest areas from the capital are Kerinci Regency and Sungai Penuh City which are $\pm 600 \mathrm{~km}$ from the capital city of Jambi Province. This illustrates the spread of ASN in Jambi Province. The number of Regional Apparatus Organizations (OPD) in the Provincial Government of Jambi is 35 as shown in the Table 1.

From table. 1 obtained an illustration of the effectiveness and efficiency that has been achieved by the presence of an Online attendance application in Jambi Province during joint leave 2020. The impact of the application of the Online Attendance System for ASN in Jambi Province is the SiAbOn application breaking the chain of COVID-19 deployment. With the presence of SiAbOn, the ASN must be obedient and disciplined to stay at home while undergoing activities, not leaving the house that could endanger the ASN but discipline and performance can still be monitored. 
Online Absention System As Implementation Of Asn Management In The New Normal Era In Jambi Province Harkeni \& Susianti

Table 1.

Online Attendance System Data (SiAbOn) Jambi Provincial Government

\begin{tabular}{|c|c|c|c|c|c|c|c|c|c|c|c|c|c|c|}
\hline \multirow[t]{4}{*}{ No } & \multirow{4}{*}{$\begin{array}{l}\text { NAMA PERANGKAT DAERAH PEMERINT AH } \\
\text { PROVINSI JAMBI }\end{array}$} & \multirow{4}{*}{$\begin{array}{c}\text { IUMLAH } \\
\text { PNS }\end{array}$} & \multicolumn{12}{|c|}{ TANGGAL } \\
\hline & & & \multicolumn{4}{|c|}{23 May 2020} & \multicolumn{4}{|c|}{24 May 2020} & \multicolumn{4}{|c|}{25 May 2020} \\
\hline & & & \multicolumn{2}{|c|}{ PAGI } & \multicolumn{2}{|c|}{ SORE } & \multicolumn{2}{|c|}{ PAGI } & \multicolumn{2}{|c|}{ SORE } & \multicolumn{2}{|c|}{ PAGI } & \multicolumn{2}{|c|}{ SORE } \\
\hline & & & $\begin{array}{l}\text { JUMLAH } \\
\text { ABSEN }\end{array}$ & $\begin{array}{l}\text { IUMLAH } \\
\text { TIDAK } \\
\text { ABSEN }\end{array}$ & $\begin{array}{l}\text { JUMLAH } \\
\text { ABSEN }\end{array}$ & \begin{tabular}{|c|} 
TUMLAH \\
TIDAK \\
ABSEN
\end{tabular} & $\begin{array}{l}\text { JUMLAH } \\
\text { ABSEN }\end{array}$ & \begin{tabular}{|c|} 
IUMLAA \\
TIDAK \\
ABSEN
\end{tabular} & \begin{tabular}{|l|} 
JUMLAH \\
ABSEN
\end{tabular} & $\begin{array}{l}\text { IUMLAH } \\
\text { TIDAK } \\
\text { ABSEN }\end{array}$ & \begin{tabular}{|l} 
JUMLAH \\
ABSEN
\end{tabular} & \begin{tabular}{|c|} 
JUMLAH \\
TIDAK \\
ABSEN
\end{tabular} & $\begin{array}{l}\text { JUMLAH } \\
\text { ABSEN }\end{array}$ & $\begin{array}{l}\text { IUMLAH } \\
\text { TIDAK } \\
\text { ABSEN }\end{array}$ \\
\hline 1 & 2 & 3 & 4 & 5 & 6 & 7 & 9 & 10 & 11 & 12 & 13 & 14 & 15 & 16 \\
\hline 1 & Sekretariat Daerah & 498 & 418 & 80 & 423 & 75 & 424 & 74 & 423 & 75 & 447 & 51 & 428 & 70 \\
\hline 2 & Sekretar iat DPRD & 69 & 62 & 7 & 60 & 9 & 63 & 6 & 65 & 4 & 66 & 3 & 66 & 3 \\
\hline 3 & Inspektorat & 96 & 91 & 5 & 93 & 3 & 91 & 5 & 90 & 6 & 92 & 4 & 92 & 4 \\
\hline 4 & Dinas Pendidikan & 5546 & 5109 & 437 & 5036 & 510 & 4942 & 604 & 5054 & 492 & 5105 & 441 & 5128 & 418 \\
\hline 5 & Dinas Kesehatan & 313 & 289 & 24 & 289 & 24 & 284 & 29 & 296 & 17 & 297 & 16 & 297 & 16 \\
\hline 6 & Dinas Kehutanan & 405 & 369 & 36 & 371 & 34 & 377 & 28 & 381 & 24 & 387 & 18 & 384 & 21 \\
\hline 7 & Dinas Kepemudaan dan Olahraga & 99 & 96 & 3 & 95 & 4 & 91 & 8 & 94 & 5 & 96 & 3 & 96 & 3 \\
\hline 8 & Dinas Kom unikasi dan Inform atika & 52 & 47 & 5 & 47 & 5 & 48 & 4 & 47 & 5 & 48 & 4 & 46 & 6 \\
\hline 9 & Dinas Kebudayaan dan Pariwisata & 121 & 114 & 7 & 113 & 8 & 115 & 6 & 116 & 5 & 117 & 4 & 116 & 5 \\
\hline 10 & $\begin{array}{l}\text { Dinas Tanaman Pangan Hortikutura dan } \\
\text { Peternakan }\end{array}$ & 302 & 280 & 22 & 277 & 25 & 276 & 26 & 282 & 20 & 282 & 20 & 284 & 18 \\
\hline 11 & Dinas Perkebunan & 116 & 100 & 16 & 100 & 16 & 98 & 18 & 100 & 16 & 99 & 17 & 103 & 13 \\
\hline 12 & Dinas Sosial Kependudukan dan Catatan Sipil & 129 & 119 & 10 & 117 & 12 & 118 & 11 & 113 & 16 & 122 & 7 & 124 & 5 \\
\hline 13 & Dinas Pekerjaan Umum dan PR & 277 & 234 & 43 & 231 & 46 & 239 & 38 & 238 & 39 & 244 & 33 & 246 & 31 \\
\hline 14 & Dinas Per pustakaan dan Arsip Dae rah & 94 & 72 & 22 & 73 & 21 & 70 & 24 & 73 & 21 & 72 & 22 & 74 & 20 \\
\hline 15 & Dinas Per industrian dan Perdagangan & 117 & 107 & 10 & 105 & 12 & 101 & 16 & 105 & 12 & 106 & 11 & 106 & 11 \\
\hline 16 & Dinas Koperasi dan UMKM & 64 & 54 & 10 & 55 & 9 & 52 & 12 & 56 & 8 & 55 & 9 & 58 & 6 \\
\hline 17 & Dinas Energi dan Sumber Daya Mineral & 81 & 79 & 2 & 80 & 1 & 77 & 4 & 78 & 3 & 80 & 1 & 80 & 1 \\
\hline 18 & SATPOL PP dan Pemadam Kebakaran & 176 & 145 & 31 & 146 & 30 & 150 & 26 & 149 & 27 & 152 & 24 & 149 & 27 \\
\hline 19 & Dinas Kelautan dan Perikanan & 154 & 148 & 6 & 149 & 5 & 145 & 9 & 151 & 3 & 149 & 5 & 152 & 2 \\
\hline 20 & Dinas Lingkungan Hidup & 98 & 94 & 4 & 97 & 1 & 92 & 6 & 95 & 3 & 98 & 0 & 96 & 2 \\
\hline 21 & Dinas Ketaha man Pangan & 75 & 72 & 3 & 72 & 3 & 72 & 3 & 70 & 5 & 72 & 3 & 74 & 1 \\
\hline 22 & Dinas Penanaman Modal dan FTSP & 73 & 67 & 6 & 71 & 2 & 70 & 3 & 70 & 3 & 69 & 4 & 69 & 4 \\
\hline 23 & Dinas Perhubungan & 67 & 57 & 10 & 55 & 12 & 60 & 7 & 58 & 9 & 62 & 5 & 63 & 4 \\
\hline 24 & Dinas Tenaga Kerja dan Transmigrasi & 145 & 140 & 5 & 140 & 5 & 135 & 10 & 137 & 8 & 137 & 8 & 140 & 5 \\
\hline 25 & Badan Perencanaan dan Pembangunan Daerah & 102 & 89 & 13 & 87 & 15 & 87 & 15 & 87 & 15 & 94 & 8 & 93 & 9 \\
\hline 26 & Badan Kepegawaian Daerah & 82 & 78 & 4 & 79 & 3 & 79 & 3 & 79 & 3 & 80 & 2 & 80 & 2 \\
\hline 27 & Badan Pengemb angan Sumber Daya Manusia & 94 & 90 & 4 & 88 & 6 & 92 & 2 & 92 & 2 & 92 & 2 & 92 & 2 \\
\hline 28 & Badan Penelitian dan Pengembangan Daerah & 54 & 51 & 3 & 51 & 3 & 50 & 4 & 51 & 3 & 51 & 3 & 51 & 3 \\
\hline 29 & Badan Keuangan Daerah & 300 & 273 & 27 & 268 & 32 & 275 & 25 & 278 & 22 & 279 & 21 & 278 & 22 \\
\hline 30 & Badan Penanggulangan Bencana Daerah & 33 & 31 & 2 & 29 & 4 & 28 & 5 & 30 & 3 & 31 & 2 & 31 & 2 \\
\hline 31 & Badan Kesatuan Bangsa dan Politik & 60 & 59 & 1 & 56 & 4 & 57 & 3 & 58 & 2 & 56 & 4 & 60 & $\circ$ \\
\hline 32 & Badan Penghubung Daerah & 59 & 56 & 3 & 56 & 3 & 56 & 3 & 55 & 4 & 56 & 3 & 56 & 3 \\
\hline 33 & RSUD Raden Mattaher & 907 & 813 & 94 & 789 & 118 & 786 & 121 & 808 & 99 & 831 & 76 & 820 & 87 \\
\hline 34 & RS jiwa & 285 & 244 & 41 & 240 & 45 & 246 & 39 & 253 & 32 & 259 & 26 & 256 & 29 \\
\hline 35 & $\begin{array}{l}\text { Dinas Pemberdayaan Perempuan, } \\
\text { Perindungan Anak dan Pengendalian }\end{array}$ & 71 & 69 & 2 & 68 & 3 & 68 & 3 & 66 & 5 & 68 & 3 & 68 & 3 \\
\hline & TOTAL PNS & 11214 & 10216 & 998 & 10106 & 1108 & 10014 & 1200 & 10198 & 1016 & 10351 & 863 & 10356 & 858 \\
\hline & TOTAL DALAM PERSEN $\%$ & $100 \%$ & $91,10 \%$ & $8,90 \%$ & $90,11 \%$ & $9.89 \%$ & $89,30 \%$ & $10,70 \%$ & $90,94 \%$ & $9,06 \%$ & $92,30 \%$ & $7,70 \%$ & 92,35 & $7,65 \%$ \\
\hline
\end{tabular}

While Figure. 1 and Figure 2 display a graph that explains the fact that the discipline of the Jambi Provincial Government's ASN in attendance is fairly adequate. At the beginning of the application of SiAbon until the second day, as many as $9.8 \%$ up to $10.7 \%$ ASN did not attend. On the third day of online attendance, 858 ASN Jambi Provincial Government were absent.
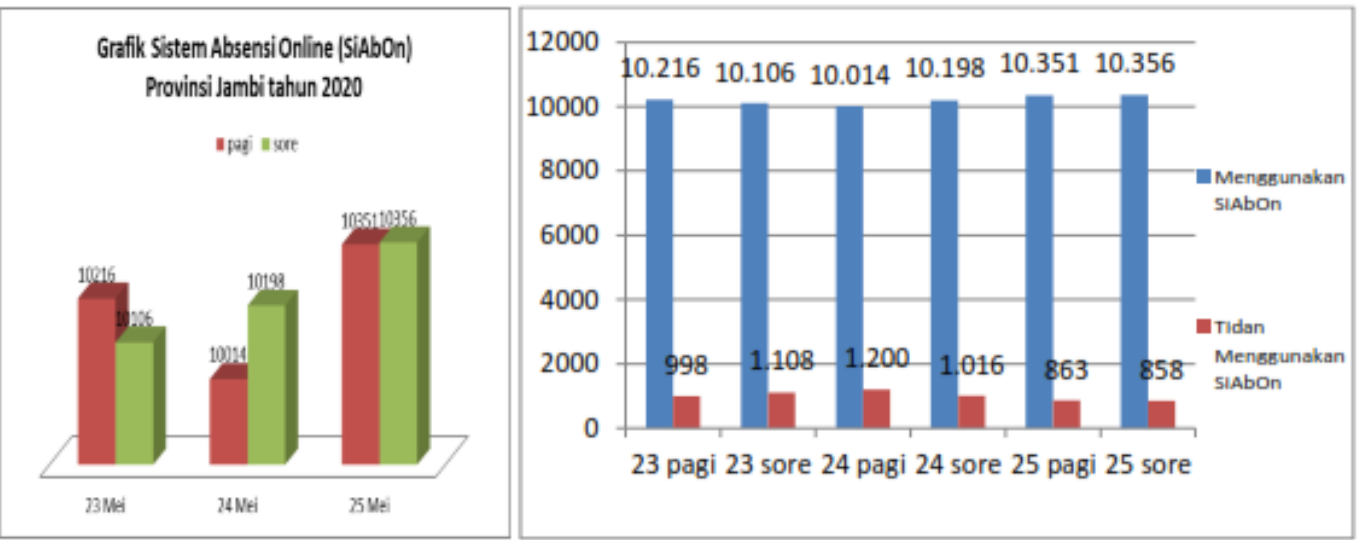

Figure 1. Data Online Attendance System (SiAbOn) Jambi Provincial Government 
On the third day of the application of SiAbOn, the number of non-absent ASNs was reduced compared to the previous day. The researcher is part of the Jambi Provincial Government ASN who conducted online attendance with SiAbOn during joint leave and national holidays in 2020 in the framework of Eid al-Fitr. Many factors constrain the absence of ASN in online attendance include: (1) the ignorance in downloading the SiAbOn application. Some ASNs do not have knowledge of information technology alias technology illiteracy; (2) ASN does not have an android mobile/smartphone that supports online attendance; (3) network problems in Jambi Province are also an obstacle. Not all areas in Jambi Province have internet access available through $4 \mathrm{G}$ networks, some cellular network areas are still using $3 \mathrm{G}$ networks or sometimes only $2 \mathrm{G}$, so not all internet network areas are in good condition. Many factors that constrain the application of online attendance. The SiAbOn Online Attendance System was also recently developed. Minimum preparation and short time, including factors that cause tissue problems during absenteeism; and (4) infrastructure preparation in the Department of Communication and Information is still very limited.

Information about the condition of the internet network in Jambi Province can be seen from the index results of the evaluation of the Electronic Based Government System (SPBE) for Jambi Province. In 2019 (SPBE) evaluated the performance of ministries, institutions, and local governments. The SPBE evaluation results for the Jambi Province namely the Jambi Province SPBE index are 1.61 with a lacking predicate. The predicate is lacking in matters relating to the administration of government which utilizes technology and communication to the public. SPBE is a government organization that utilizes information and communication technology to provide services to Users (SPBE, 2019). The Work from Home (WFH) policy that has been set by the government for ASN employees in this government agency has encouraged the use of SPBE more optimally. The mobile company Opensignal states that network problems in Jambi Province are below the average of other provinces in Indonesia. Data from the Opensignal mobile analytics company in 2019 observed several significant improvements in cellular networks for several regions in Indonesia and obtained data such as Figure 3 below.

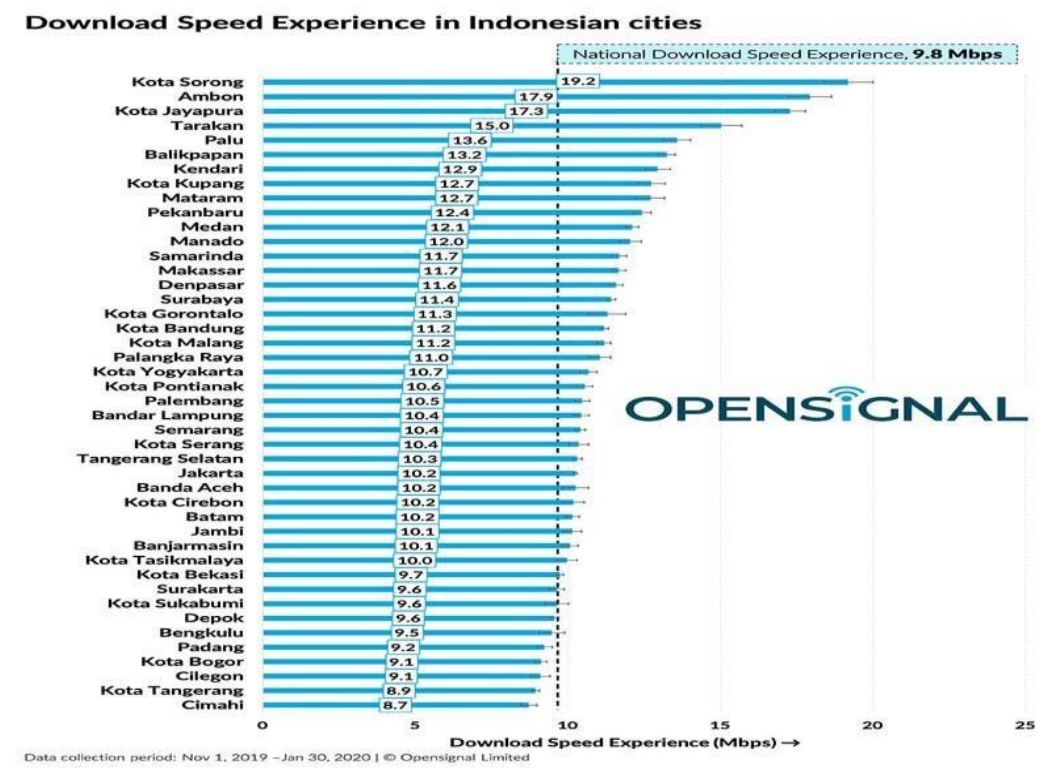

Figure 3.

Results of the Opensignal survey for Jambi Province 
According to the results of the Opensignal survey, Jambi Province ranks 13th from the bottom for "Download speed experience in Indonesian cities" (Fatria, 2020). From the results of the analysis of the data above on the presence of the Jambi Provincial Government ASN during national holidays and joint leave for Eid in 2020, the results obtained are quite satisfactory compared to the network problems experienced by the ASN every day. That is due to the preparation of the implementation of SiAbOn which is only 14 working days with the distribution of employees distributed more than $600 \mathrm{~km} 2$ but the online attendance system is implemented, of more than $92 \%$ ASNs implemented this new system. The success rate of the SiAbOn application is a new setting in recording employee attendance using a smartphone.

The implementation of ASN management in principle adheres to the principle of effective and efficient that fulfills the target or goal on time and following established plans. To ensure the efficiency and effectiveness of ASN, a good attendance system is needed. The online attendance system is a wise choice for implementing ASN management by Government Regulation No. 11 of 2017 concerning the Management of Civil Servants.

COVID-19 became the reality of a disease that changed the social structure of society. Social behavior changes so do social cohesion. Ways (usage), habits (folkways), behavior (mores), and customs (custom) also adapted (Syaifudin, 2020). It is expected that this research can provide new studies for other regions in Indonesia in implementing management for ASN in the new normal era.

Online Attendance System application requires more intensive and massive socialization to all ASN Jambi Province. The enhancement of supporting devices for SiAbOn applications requires attention from the Jambi Provincial Government. The Communication and Information Agency needs to develop the iOS version of SiAbOn because SiAbOn can only be used on an android smartphone.

\section{CONCLUSION}

The application of online attendance recording through the SiAbOn app in the Jambi Provincial Government environment that is limited in its internet infrastructure facilities but has been successfully held, hoping this will be an inspiration to other regions in Indonesia that have internet infrastructure equivalent or better than those in Jambi Province. The hard work and technological development that continues to be carried out by the Jambi Province Office of Communication and Information is commendable. Amid the limitations of the Jambi Provincial Communication and Information Office, this agency was able to create an effective and efficient program to prevent ASN from contracting Covid-19.

\section{REFERENCES}

Andini, A. F., Irzal, M., \& Arafiyah, R. (2017). Perancangan dan Implementasi Sistem Absensi Online Berbasis Android di Lingkungan Universitas Negeri Jakarta. J-KOMA: Jurnal Ilmu Komputer dan Aplikasi, 1(1), 1-10. Retrieved from http://journal.unj.ac.id/unj/index.php/jkoma/article/download/3857/2881/

Andini, T. (2019, Februari 11). 4 Keuntungan Menggunakan Absensi Online. Retrieved from www.weefer.co.id: https://www.weefer.co.id/2019/02/4-keuntungan-menggunakanabsensi-online/ 
BKN. (2020, April 24). Surat Edaran BKN RI Nomor 11/SE/IV/2020. Tentang Pedoman Penjatuban Hukuman Disiplin Bagi Aparatur Sipil Negara Yang Melakukan Kegiatan Bepergian ke Luar Daerah dan/atau Kegiatan Mudik Pada Masa Kedaruratan Kesehatan Masyarakat. Jakarta. Retrieved from https://www.bkn.go.id/wp-content/uploads/2020/04/SEMudik.pdf

BPS Provinsi Jambi. (2019). Luas, Penduduk, Kepadatan Penduduk Provinsi Jambi menurut Kabupaten/Kota, 2018. Retrieved from https://jambi.bps.go.id/dynamictable/2019/09/11/1229/luas-penduduk-kepadatanpenduduk-provinsi-jambi-menurut-kabupaten-kota-2018.html

Bramasta, D. B. (2020, Mei 20). Mengenal Apa Itu New Normal di Tengah Pandemi Corona. Retrieved from Kompas.com: https://www.kompas.com/tren/read/2020/05/20/063100865/mengenal-apa-itu-newnormal-di-tengah-pandemi-corona-?page $=$ all

Fatria, J. (2020, Maret 14). Daftar Kecepatan Internet 44 Kota Besar Di Indonesia. Retrieved from www.kalbaronline.com: https://www.kalbaronline.com/2020/03/14/daftar-kecepataninternet-44-kota-besar-di-indonesia/

Jambi Independent. (2020, Mei 18). jambi-independent.co.id. Retrieved from Dilarang Mudik, ASN Dipantau: https://jambi-independent.co.id/read/2020/05/18/50953/dilarang-mudikasn-dipantau

Kadir, A., \& Triwahyuni, T. C. (2013). Pengantar Teknologi Informasi. Yogyakarta: Andi.

Keputusan Presiden Republik Indonesia. (2020). Nomor 11 Tahun 2020 tentang Penetapan Kedaruratan Kesehatan Masyarakat Corana Virus Disease 2019.

Keputusan Presiden Republik Indonesia. (2020). Nomor 12 tahun 2020 tentang Penetapan Bencana Nonalam Penyebaran Corona Virus Disease 2019 (Covid-19) sebagai Bencana Nasional.

MUSTARI, F. (2018). APLIKASI ABSENSI GURU PADA SEKOLAH BERBASIS ANDROID (STUDI KASUS SMP NEGERI 1 BULUKUMBA). Skripsi. Makassar: FAKULTAS SAINS DAN TEKNOLOGI UIN ALAUDDIN MAKASSAR. Retrieved from http:/ / repositori.uin-alauddin.ac.id/13944/1/Fachrival\%20Mustari.pdf

Pemerintah Provinsi Jambi. (2020, Maret 20). http://jambiprov.go.id/. Retrieved from TINGKATKAN PENCEGAHAN PENYEBARAN COVID-19, FACHRORI ADAKAN PENYESUAIAN SISTEM KERJA ASN PEMPROV JAMBI: http://jambiprov.go.id/v2/berita-tingkatkan-pencegahan-penyebaran-covid19-

fachrori-adakan-penyesuaian-sistem-kerja-asn-pemprov-jambi.html

Peraturan Pemerintah Republik Indonesia. (2010, Juni 6). TENTANG DISIPLIN PEGAWAI NEGERI SIPIL. Retrieved from https://jdih.kemenkeu.go.id/fullText/2010/53TAHUN2010PP.HTM\#: :text=PERA TURAN\%20PEMERINTAH\%20TENTANG\%20DISIPLIN\%20PEGAWAI\%20NE GERI $\% 20$ SIPIL.\&text=Dalam $\% 20$ Peraturan $\% 20$ Pemerintah $\% 20$ ini $\% 20$ yang $\% 20$ dima ksud $\% 20$ dengan $\% 3$ A\&text $=$ Pelanggaran $\% 20$ disiplin $\% 20$ adalah $\% 20$ seti

Peraturan Pemerintah Republik Indonesia. (2017, April 7). tentang Manajemen Pegawai Negeri Sipil. Jakarta. Retrieved from https://peraturan.bpk.go.id/Home/Details/5831/pp-no11-tahun-2017

Sekretariat Kabinet Republik Indonesia. (2020, April 14). setkab.go.id. Retrieved from Presiden Tetapkan Bencana Nonalam Penyebaran Covid-19 sebagai Bencana Nasional: 257 | Ilomata International Journal of Management Vol. 1 No. 4 October 2020 
https://setkab.go.id/presiden-tetapkan-bencana-nonalam-penyebaran-covid-19sebagai-bencana-

nasional/\#: :text=Selain \%20itu\%2C\%20World\%20Health\%20Organization,Pandemic $\% 20$ tanggal $\% 2011 \% 20$ Maret $\% 202020 . \&$ text $=\%$ E2\%80\%9CMenyatakan $\% 20$ bencana $\% 20$ nonalam $\% 20$ yang $\% 20$ diak

SPBE. (2019). MONITORING DAN EVALUASI SPBE. Retrieved from spbe.go.id: https://spbe.go.id/moneval

Syaifudin. (2020, Juni 10). Negara, Masyarakat dan Era New Normal. Retrieved from kolom.tempo.co: https://kolom.tempo.co/read/1351996/negara-masyarakat-dan-eranew-normal

Undang Undang RI. (2014, Januari 15). NOMOR 5 TAHUN 2014. TENTANG APARATUR SIPIL NEGARA. Jakarta. Retrieved https://jdih.kemenkeu.go.id/fullText/2014/5TAHUN2014UU.HTM

Wibowo. (2007). Manajemen Kinerja (5th ed.). Jakarta: PT Raja Grafindo Persada. 